\title{
On the Duty to Be an Attention Ecologist
}

\author{
Timothy Aylsworth and Clinton Castro
}

Florida International University, Department of Philosophy Pre-production copy.

Please cite to final version: $\underline{\text { https://doi.org/10.1007/s13347-022-00514-6 }}$

\begin{abstract}
The attention economy - the market where consumers' attention is exchanged for goods and services - poses a variety of threats to individuals' autonomy, which, at minimum, involves the ability to set and pursue ends for oneself. It has been argued that the threat wireless mobile devices pose to autonomy gives rise to a duty to oneself to be a digital minimalist, one whose interactions with digital technologies are intentional such that they do not conflict with their ends. In this paper, we argue that there is a corresponding duty to others to be an attention ecologist, one who promotes digital minimalism in others. Although the moral reasons for being an attention ecologist are similar to those that motivate the duty to oneself, the arguments diverge in important ways. We explore the application of this duty in various domains where we have special obligations to promote autonomy in virtue of the different roles we play in the lives of others, such as parents and teachers. We also discuss the consequences of our arguments for employers, software developers, and policy makers.
\end{abstract}

Keywords: ethics of technology; Kantian ethics; autonomy

\section{Introduction}

The attention economy - the market where consumers' attention is exchanged for goods and services - poses a variety of threats to individuals' autonomy, which, at minimum, involves the ability to set and pursue ends for oneself. The "free" apps and web services that are a cornerstone of this market are in fact paid for with users' attention, a precious resource to advertisers who have an interest in keeping users on their wireless mobile devices in excess. But the wireless mobiles devices, such as smartphones, that deliver these services are often bad for users, not only in terms of well-being - to cite a recent study, it has been estimated that one fourth of children and young people suffer from problematic smartphone use, "a pattern of 
behaviour that mirrors that of a behavioural addiction," which is associated with "depression, anxiety, high levels of perceived stress, and poor sleep" (Sohn et al. 2019, 7) — but also in terms of capabilities essential to the exercise of autonomy, such as attentional, mnemonic, self-regulation and cognitive capacities (see Wilmer et al. 2017 for an overview).

It has been argued elsewhere that the threat wireless mobile devices pose to autonomy gives rise to a duty to oneself — grounded in a Kantian obligation to foster and safeguard autonomy — to be a digital minimalist, one whose interactions with digital technologies are intentional such that they do not conflict with their ends. ${ }^{1}$ As Aylsworth and Castro (2021) argue, digital minimalism, construed in terms of autonomous use, does not by any means require us to eliminate our use of smartphones altogether. In many ways, these devices can enhance autonomy rather than inhibit it. They provide many useful tools, give us helpful reminders, and often allow us to pursue our ends more effectively. Thus, digital minimalism can endorse the use of technology when it is employed in ways that enhance our autonomy, while nevertheless condemning the forms of compulsive usage that are inconsistent with our capacity to set and pursue ends autonomously.

In this paper, we argue that there is a corresponding duty to others - also grounded in the duty to foster and safeguard autonomy — to be an attention ecologist, one who promotes digital minimalism in others. Although the moral reasons for being an attention ecologist are similar to those that motivate the duty to oneself, the arguments diverge in important ways. This is because the nature of duties to oneself (which are conditioned by the sovereignty we have over

\footnotetext{
${ }^{1}$ See Aylsworth and Castro (2021). See also Lo Re (2022).
} 
ourselves) are different from other-regarding duties (which are conditioned by the sovereignty others enjoy over themselves).

As we will demonstrate, the demands of the general duty to be an attention ecologist are necessarily imprecise. The duty to promote digital minimalism in others takes on different forms depending on the nature of our relationship to the person in question. This is because our obligation to promote the autonomy of other agents is especially demanding in certain contexts. We begin by considering two roles where the duty is particularly salient: parent and teacher. These roles are obviously not exhaustive, but it is our hope that in arguing for the duty and then applying it to these cases that we show how it could be extended to others. We shed some light on how this might be done by briefly exploring the consequences of our arguments for employers, software developers, and policy makers. In some cases, we have a positive duty to cultivate autonomy insofar as we are already committed to the project of fostering someone's autonomy (such as parents and teachers). In other cases the duty is negative; this is true of software developers who ought to refrain from undermining users' autonomy. And finally, there are cases where we are under no obligation to change someone's relationship with technology. In addition to these moral duties, there is an argument to be made for regulating industries that involve highly addictive products. This has already been done in the cases of gambling, alcohol, and tobacco. So policymakers have an important role to play in regulating the attention economy as well.

The structure of the paper is as follows. In the next section, we present the empirical data on smartphone addiction. In section 3 , we present the moral argument for the duty to protect the autonomy of other rational agents. In section 4, we explore the application of this duty in various 
domains where we have special obligations in virtue of the different roles we play in the lives of others. In section 5 we offer a summary of our conclusions.

\section{The Threat of Smartphone Addiction}

Phones - whether smart or not — are designed to grab attention. This is why they come equipped with lights, ringers, and vibration motors. Smartphones and similar devices take their ability to capture attention to extreme levels. They deliver alerts that have little to do with communication with one's contacts (e.g., news alerts), and train their owners to check them compulsively. It has been estimated that the average smartphone user touches their phone an eye-popping 2,617 times per day (Winnick and Zolna 2016) and that the average U.S. consumer spends five hours on their phone per day (Provision Living, 2020). As addiction psychiatrist Judson Brewer puts it: "Forget cocaine-Facebook introduced the like button and we all became addicted" (Brewer 2021, p. 159).

The interruptions fueled by notifications and the behaviors associated with problematic smartphone use are not costless. ${ }^{2}$ Exposure to notifications - even when they go unchecked have been shown to negatively affect performance on concentration-based tasks (Stothart et al., 2015). Indeed, the mere presence of a cell phone has been shown to negatively impact cognitive functioning (Thornton et al. 2014). Further, phone checking often leads to a number of unrelated in-phone tasks, e.g. checking one's email upon receiving a text (Wilmer et al. 2017). This has been shown to delay the completion of the initial in-phone task by up to $400 \%$ (Leiva et al., 2012). In addition to the impediments caused by phone checking, the resumption of tasks after

\footnotetext{
${ }^{2}$ We owe the empirical information in this and the following two paragraphs - and some of their organization to-Wilmer et al. (2017)'s excellent review of the research of the links between mobile technology habits and cognitive functioning.
} 
interruptions is itself a source of error (known as "resumption errors") (Monk, 2004; Cades et al., 2007; Brumby et al., 2013). As Wilmer et al. (2017) et al. note, the tendency to commit these errors increase sharply when the interruption is longer than 15 seconds (Monk et al., 2008), a threshold that smartphone interruptions frequently exceed (Leiva et al., 2012).

Not only do wireless mobile devices negatively affect our ability to focus on and execute our ongoing tasks, they also negatively affect general cognitive function. Smartphone use has been linked to depression (see Sohn et al. 2019) and diminished quality of sleep (see Cain and Gradisar 2010 or Sohn et al. 2019), which are known to adversely affect cognitive performance. ${ }^{3}$

In addition to their effects on our attention and cognitive functioning, wireless mobile devices are powerful tools for behavior modification. As Nir Eyal (2014) - a design guide that introduces a popular method for influencing users' behavior notes-many smartphone applications are designed to "hook" us, that is, to get us to habitually use them. Many of these applications follow Eyal's simple, powerful formula: trigger the user to use their phone, get the user to perform some action, tie the action to a variable reward (variation being very important, as it leverages the psychology of other addictive activities, such as the pulling of the lever of a slot machine), and then have the user make an investment so they will be more easily drawn into the next pavlovian, habit-forming trigger-action-reward-investment "Hook Cycle." It is worth noting here that Eyal is keen to note that these cycles—-because of the variable reward—sets one's "brain dopamine system aflutter with the promise of reward" which "suppresses the areas of the brain associated with judgement and reason while activating the parts associated with wanting and desire" (Eyal 2014).

\footnotetext{
${ }^{3}$ See McIntyre et al. (2015) and Millan et al. (2012) for the link between depression and cognitive performance; see Lim and Dinges (2008) for the link between diminished quality of sleep and cognitive performance.
} 
We indeed seem to be "hooked". Surveys based on self-reports repeatedly show that people use their phones more than they would like. For instance, Beningfield (2018) reports that $39 \%$ of respondents claimed to use their phone more than they wanted to, with this number being higher - $60 \%$ - among younger users (i.e., users between the ages of 18 and 34).

So far, we have given an overview of the main concerns about mobile phone use that we will be drawing from and addressing in this paper. We do not take this to be a comprehensive list of concerns. We take it that FOMO (fear of missing out) and NOMOphobia (NO MObile phone phobia) are also drivers of smartphone addiction. Some of our concerns overlap with these phenomena-such as the above observation that unchecked notifications interfere with concentration-but we unfortunately do not have the space to fully explore every concern, including these, in this paper. What we would like to note for the time being is that this paper lacks, among other things, deep engagement with the question of what to replace phone use with. It has been observed that "doing nothing" (e.g., standing in an elevator not looking at one's phone) has become stigmatized (Odell 2019). A recurrent theme in these discussions is that people are increasingly unwilling to experience boredom, as phones have made it possible to be constantly distracted. Some psychologists and neuroscientists, like Mann (2018) have argued that boredom has some benefits and might even be critical to brain health. On a fuller accounting of what being an attention ecologist or digital minimalist might involve, we must engage with questions about accommodating the absence of phone use and related matters, i.e., the accommodation of doing nothing.

We take it that the above considerations make a strong case that wireless mobile devices pose a threat to autonomy. After all, these devices can be detrimental to capacities crucial for it 
(such as, but not limited to, attention and cognitive functioning). They promote habits that are at odds with some of our ends (such as the end of not spending excessive amounts of time on our phones, getting enough sleep, having face-to-face interactions, and overcoming stress, anxiety, and depression). They also make us heteronomous (when the Hooked system works, this is manifested by behaviors that have been intentionally instilled in us by outside forces, whose interests are at odds with our own).

With our key empirical observations in place, we can now turn to the question of the moral duty that comes on their heels: Insofar as we have an obligation to foster and safeguard autonomy in others, we have a duty to be attention ecologists.

\section{The Duty of Respect for Rational Agency}

Our aim in this section is to argue that we have a moral obligation to protect the autonomy of other rational agents. While the grounding for this duty is generally Kantian, the argument does not depend entirely on Kant's own views about particular duties to oneself. ${ }^{4}$ Our argument does rely, however, on a Kantian commitment to the value of autonomy and our obligation to respect this capacity. We believe that these commitments are plausible and that they suffice to ground the duty in question. At the end of the section we briefly consider other normative theories that could also offer moral reasons to protect others from mobile phone

\footnotetext{
${ }^{4}$ This would be problematic for several reasons. For example, a moral obligation to protect ourselves from mobile phone addiction could potentially be grounded in Kant's claims about the duty to pursue our natural perfection (e.g., cultivating talents, avoiding the vices of drunkenness and gluttony, etc.), but Kant's commitment to certain teleological claims in this domain also motivate his arguments against homosexuality and masturbation (see, for example, MS 6:421-27). Given that we wish to avoid such commitments, we make an argument that depends only on Kant's claims about the value of rational agency (humanity), and our duties to respect it in our own person and that of others. Our argument can thus avoid implausible teleological claims and the duties that supposedly follow from them.
} 
addiction. Kantian ethics may offer the most direct route to the duty, but it is by no means the only one.

Kant's formula of humanity requires us to "use humanity, whether in your own person or in the person of any other, always at the same time as an end, never merely as a means" ( $G$ 4:428). Kant frequently glosses 'humanity' as "rational nature" ( $G$ 4:428), and he makes it clear that he is particularly concerned with our distinctive rational capacity to set and pursue ends autonomously ( $G 4: 437 ; M S$ 6:392). Kant tended to use the word 'autonomy' in a narrowly moral sense; an agent's autonomy consists in the capacity to bind herself through the moral law — self-legislation through reason alone. In what follows, our usage will diverge from Kant's as we use the word 'autonomy' to refer to 'personal autonomy.' This is closer to what Kant calls 'humanity' — "the capacity to set oneself an end" (MS 6:392). ${ }^{5}$ When we talk about the moral importance of promoting or protecting 'autonomy,' this should be understood as a fulfillment of the duty to respect 'humanity."

When discussing the obligations that stem from our duty to respect humanity, Kant identifies exactly two ends that we are morally required to set for ourselves: our own perfection,

\footnotetext{
${ }^{5}$ For a more detailed discussion of Kant on personal autonomy and the distinction with moral autonomy, see Taylor (2005). Taylor is responding to critics like Waldron who argue that Kant does not even have a concept of personal autonomy. See Waldron (2005).

${ }^{6}$ There are many competing concepts of personal autonomy, and we believe our argument can succeed without committing to any particular account. For example, one contention of our argument is that the problematic use of smartphones can threaten autonomy (understood as 'personal autonomy' or Kant's 'humanity') insofar as it weakens certain cognitive capacities (attention, memory, etc.). The failure of autonomy in such cases could be understood according to the Frankfurt/Dworkin model of first- and second-order desires. Aylsworth and Castro (2021) discuss an agent who wants to read books but continually fails because of her social media addiction. Her first-order desire to check her phone is inconsistent with her second-order desires. Her second-order desire is to have the first-order desire to read books (or, alternatively, she wishes to purge her alien desire to be interrupted by her phone while she tries to read). So the agent is not autonomous according to the Frankfurt/Dworkin model. See Frankfurt (1971) and Dworkin (1988). The failure of autonomy could also be understood according to Watson's view in the sense that the agent's desires are inconsistent with her evaluative judgments (Watson 1975). It could also be understood through Bratman's view involving the agent's long-term plans (Bratman 1979, 2007). Given that each view of personal autonomy can adequately explain how smartphone addiction is inconsistent with autonomy, we have not wedded our argument to a particular view.
} 
and the happiness of others. On Kant's view, developing our rational capacities is what makes us worthy of our "humanity."7 Because of this, he thinks we have a duty to ourselves to cultivate our rational nature and to avoid vices that diminish or weaken these capacities. The duty to perfect ourselves (both morally and naturally) is one of the only positive duties we have to ourselves. ${ }^{8}$ The other obligatory end is the happiness of others. This is the duty of beneficence, and Kant defines it in terms of an obligation to promote others' ends as if they were our own (provided, of course, that their ends are morally permissible).

Both of these are "wide" (meritorious) duties that allow for some latitude or "playroom" when it comes to their fulfillment (MS 6:390). Although we are required to cultivate our capacities and to promote the happiness of others, we can use discretion when deciding how much, how often, and in what circumstances we ought to pursue these ends. Imperfect duties like these require us to adopt an end, but they do not tell us exactly how to pursue it.

When discussing these two obligatory ends, Kant insists that the obligations are asymmetrical. Although we have a duty to pursue the happiness of others and to perfect ourselves, we do not have a duty to promote our own happiness, and we do not have a duty to promote the moral perfection of others (MS 6:386). His brief argument for this position rests on the "ought implies can" principle. In the case of our own happiness, this is something that everyone already pursues naturally (and thus he thinks the normative language of "oughts" is out

\footnotetext{
${ }^{7}$ He writes, "The capacity to set oneself an end — any end whatsoever — is what characterizes humanity (as distinguished from animality). Hence there is also bound up with the end of humanity in our own person the rational will, and so the duty, to make ourselves worthy of humanity by culture in general, by procuring or promoting the capacity to realize all sorts of possible ends, so far as this is to be found in the human being himself. In other words, the human being has a duty to cultivate the crude predispositions of his nature, by which the animal is first raised into the human being. It is therefore a duty in itself" (MS 6:392).

${ }^{8}$ We also have a perfect duty to scrutinize our own behavior and character, the duty of conscience. In addition to these positive duties to oneself, there are many duties of omission. Kant identifies a wide variety of vices that he thinks we must avoid in order to fulfill our duty to ourselves (e.g., drunkenness, gluttony, defiling oneself through lust, etc.). See $M S$ 6:421-29.
} 
of place). ${ }^{9}$ When it comes to the perfection of others, this pertains strictly to ends the agent sets for herself, which means that we cannot (and should not) make this our end. Kant suggests that we know too little about the ends of others, and it is simply not our place to set ends for them.

At first glance, Kant's asymmetry claim appears to present a serious problem for the duty we are defending in this paper. After all, we are claiming that we have a duty to protect the autonomy of others by encouraging them to adopt the end of digital minimalism. This would seem to be a case of promoting the moral perfection of others, and it looks like Kant is suggesting that we do not (and cannot) have any such duties.

There are three ways of responding to this problem. First, it could be argued that Kant is simply wrong on this point. Lara Denis claims that Kant's argument here "fails on three counts" (2001, 146). She sees Kant as arguing from the premise that we do not know enough about the ends of others to assist in their perfection. But even if it is true that I cannot know enough about someone else's ends to cultivate virtue on their behalf, I can nevertheless remove temptations or obstacles from their path. Kant himself recognizes such duties when discussing obligations we have to refrain from "giving scandal" (MS 6:464). And duties of beneficence could sometimes be construed as promoting someone's happiness in order to prevent them from acting contrary to duty. ${ }^{10}$ Furthermore, our acquaintance with the ends of others depends on our relationship with them. In certain cases (such as those we discuss below), our involvement in the lives of others might give us privileged access to their ends, enabling us to assist them in their pursuit of virtue. Finally, if our lack of knowledge about others' ends is an obstacle to promoting their moral

\footnotetext{
${ }^{9}$ See $G$ 4:414 for Kant's view on imperatives and the force of "ought."

${ }^{10}$ Denis approvingly cites O'Neill on this point, as O'Neill had argued that certain acts of beneficence "promote others' rational self-governance - thus non-paternalistically promoting their moral and natural perfection as well as their happiness - by removing obstacles such as hunger, poverty, coercion, deception, repressive government, and so on" (Denis 2001, 147n44). See also O’Neill $(1980,1986)$.
} 
perfection, this should constitute an equally powerful objection to the duty of beneficence. For these reasons, Denis $(1999,2001)$ rejects Kant's asymmetry and argues that we do indeed have duties to promote the perfection of others. This is certainly what later German Idealists like Fichte thought Kant should have said. ${ }^{11}$

The second way of resisting the problem is to suggest that the asymmetry is overstated. It may be true in some narrow sense that we are incapable of morally perfecting others. Moral perfection is something each agent must pursue on her own. But that does not necessarily mean that I am under no obligation whatsoever to help others in their pursuit of virtue. Indeed, Kant himself claims that our duty of beneficence includes an obligation to promote the "moral well-being" of others (MS 6:394). Allen Wood makes this qualification when discussing the asymmetry: "Kant's point could, therefore, be put this way: I do have a duty to promote my own happiness, but only insofar as my happiness falls under the heading of my perfection; and I $d o$ have a duty to promote the perfection of others, but only insofar as it falls under the heading of their happiness" $(2004,148)$. Wood goes so far as to suggest that the statement in the Metaphysics of Morals is so overstated that it does not express Kant's considered view. ${ }^{12}$

Christine Korsgaard makes this point as well, as she notes that we are sometimes placed in a privileged position (as a parent, teacher, or close friend, etc.) making it possible for us to

\footnotetext{
${ }^{11}$ Fichte argues in his System of Ethics that we are morally required to promote morality both in our own person and in others. Stefano Bacin (2021) highlights this contrast between Kant and Fichte, citing $\$ 18$ of Fichte's System of Ethics: "What I will is morality as such" and "it does not matter in the least whether this is in me or is outside me", "my end is achieved if the other person acts morally" (GA I/5: 210; SL 4: 232). Allen Wood explains how Fichte saw himself as simply trying to be a consistent Kantian on this point. Fichte stressed the ethical importance of institutions that would develop the morality of others (Wood 2016, 214).

${ }^{12} \mathrm{He}$ writes, "The mutual improvement of men's moral characters through education and religious community play such an important role in Kant's overall view of the moral destiny of man that it is impossible to take as Kant's best thinking the passage cited in which he denies that one can promote the moral good of others. Rather, it seems altogether proper to regard the critical moral philosophy, along with Kant in his most profound moral convictions, as holding that the moral good of all finite rational beings is the unqualified and unconditioned end of the finite rational moral agent" $(1970,78)$.
} 
contribute to the perfection of others: "Choosing ends on another's behalf is as impossible as it would be disrespectful, but putting others in a good position to choose ends for themselves, and to choose them well, is the proper work of parents, teachers, friends, and politicians; providing for someone's moral education as well as nurturing her self-respect is an important part of the way we do this" (1992, 331n37).

The third way of responding to the asymmetry is to suggest that the duty we advocate here is not ultimately inconsistent with Kant's position. Kant's claim in the Metaphysics of Morals is limited to "ends that are also duties." Even if we are not required to adopt the moral perfection of others as one of our ends, we may nevertheless be required to refrain from actively undermining their rational capacities. The duty to be an attention ecologist could thus be characterized negatively as an obligation to avoid leading others into technological heteronomy. When discussing the duty to promote the "moral well-being" of others, Kant makes the following remark: "it is my duty to refrain from doing anything that, considering the nature of a human being, could tempt him to do something for which his conscience could afterwards pain him, to refrain from what is called giving scandal" (MS 6:394).

Whichever reply one chooses, the duty to be an attention ecologist survives the challenge posed by Kant's asymmetry. But an additional argument is needed to connect the duties in question. Even if we have succeeded in showing that problematic cell phone use poses a threat to our autonomy and that we have a duty to protect our own autonomy, this falls short of justifying a duty to protect others from forms of technological heteronomy.

The argument for the claim that we have an imperfect duty to promote others' autonomy with respect to their use of technology is quite simple. We argued in section 2 that compulsive 
cell phone use weakens our capacity to set ends for ourselves and to pursue those ends effectively. If this empirical claim is true, then promoting others' autonomy with respect to their use of technology would simultaneously amount to making them more capable of setting and pursuing their ends. It could, therefore, be construed positively under the heading of beneficence. 13 But, as suggested above, the obligation could also be construed negatively in terms of protecting others from the threat of technological heteronomy. Given that rational agents have a duty to protect their own autonomy, we have a corresponding duty to avoid tempting them into heteronomy. ${ }^{14}$ We will bring the demands of this duty into relief in section 4.1 by exploring its implications for parents and teachers. We will explore some of its limitations in section 4.2 by considering how it might apply to other roles, namely employer, software developer, and policy maker.

Before moving on, however, it is worth mentioning that other moral theories could lead to a similar conclusion about the duty to be an attention ecologist. Consequentialists may arrive at this duty in a variety of ways. If, for instance, their list of intrinsic goods includes autonomy, then this would make the argument quite simple. We promote the good by helping others be autonomous. But even classical utilitarianism has the resources for justifying such a duty. We are suggesting that people ought to be autonomous with respect to their use of technology (particularly wireless mobile devices), and the considerations in section 2 plausibly suggest that the compulsive use of such devices is not conducive to users' happiness. We can thus promote

${ }^{13}$ Kant identifies beneficence as one of the "duties of love," and the duty of love is generally defined as "the duty to make others' ends my own" (MS 6:450). If I make someone else's end my own, then I ought to do what I can to help them pursue that end. That could include promoting digital minimalism as a means of making them better at pursuing their ends.

${ }^{14}$ A similar Kantian argument has been made with respect to persuasive advertising. Villarán (2017) argues that advertising is morally problematic because it promotes heteronomy. He argues that advertising can undermine our moral autonomy by encouraging us to be slaves to our passions. 
the happiness of others by encouraging them to use their mobile devices in ways that are consistent with their autonomy.

Perfectionist theories such as Aristotelian virtue ethics could also provide reasons for promoting digital minimalism in others. Promoting autonomous use of technology could very well be construed as a means of promoting conditions that are conducive to human flourishing. Contractualists could argue that a rule which tells us to promote the technological autonomy of others (appropriately construed) is not one that could be reasonably rejected. It would be impossible to give an exhaustive set of arguments here, but these brief explanations should suffice to show that Kantian ethics is not the only moral theory that could potentially justify the duty to be an attention ecologist.

We presented a Kantian argument in this paper simply because this seems like the most perspicuous account. Kant's moral philosophy does an especially good job of emphasizing the moral importance of autonomy. And there is something deeply plausible about Kant's claim that rational agency has a unique kind of value that makes it deserving of respect. ${ }^{15}$ And if it is true that the compulsive use of technology threatens our autonomy, then it is reasonable to conclude that we have a moral duty to protect both ourselves and others from this threat.

\section{Applications of the Duty}

Our aim in this section is to examine how the duty to be an attention ecologist arises in certain relationships and to explain how the demands of the duty vary depending on the nature of the relationship. In certain contexts, we have good reasons for concerning ourselves with the

\footnotetext{
${ }^{15}$ Defending this claim would require going well beyond the scope of our aim here. Korsgaard (1996) presents a powerful argument for this view.
} 
autonomy of others. Parents might have special duties to cultivate autonomy in their children, and teachers arguably ought to facilitate autonomy among their students.

In other domains, we might have little or no obligation to promote someone's technological autonomy. You may see someone working at a cafe who is struggling to finish a task because they keep getting interrupted by notifications from their phone, but it would not be your place to tell them how to conduct their affairs. As Korsgaard rightly pointed out, it would be disrespectful for a stranger to choose ends on their behalf, and that includes the end of digital minimalism. By contrast, it would be perfectly appropriate for a parent to limit a child's screen time in order to encourage the child to pursue other things like reading or physical activity.

We have therefore restricted our attention to contexts where we are in a position of power or privilege with respect to the ends of another person. In these domains, it is reasonable to believe that we have an obligation to promote the autonomy of the person over whom we have this power or influence. Kant certainly thought that teachers and parents have such a duty, but there are many independently plausible reasons for thinking that autonomy should be one of the aims of education and child-rearing. So we will discuss Kant's views on teaching and parenting below, but, once again, the argument does not depend on Kant's particular conception of these activities.

\subsection{Parents and Teachers}

It should come as no surprise that Kant championed autonomy as the principal aim of education (and parenting). The influence of Rousseau (especially Émile) is more noticeable here than almost anywhere else in Kant's work; he argues that the realization of freedom is the 
primary objective of the entire educational enterprise (UP 9:455). But the story does not end with the mere capacity for self-legislation; Kant believed that education should culminate in the pupil's use of freedom for its proper vocation - morality. He argued that education would be fundamentally incomplete without a moral component. And he saw parenting in much the same light, arguing that parents have an obligation to develop their children both pragmatically and morally (MS 6:280-82).

We do not need to share Kant's particularly moralistic vision of education, however, to see that there is something deeply plausible about the idea that autonomy (defined minimally as the capacity for self-government) ${ }^{16}$ is one of the most important goals of both teaching and parenting. Parents often aim to help their child grow into an adult who is capable of setting and pursuing goals independently. And it could be argued that a parent who merely satisfies the child's biological needs falls short of some important obligations in this regard. ${ }^{17}$ A parent who deliberately chooses not to cultivate the child's capacities in any way could reasonably be accused of wronging the child. ${ }^{18}$

It is for this very reason that the generally permissive framework of liberalism can justify compulsory education. Requiring parents to educate their children limits parental sovereignty,

\footnotetext{
${ }^{16}$ For more detailed discussions of Kant's views on education, see Herman (2007), Louden (2000), Cohen (2016), Roth and Formosa (2019), and Frierson (forthcoming).

${ }^{17}$ There are interesting questions about the nature and origin of parental obligations. Austin 2007 discusses an account of parental obligations according to which parents incur "custodial obligations" to their child by agreeing to take on the job (2007, 34). Austin notes that Bluestein (1982), O'Neill (1979), and Vallentyne (2002) also argue for the "consent view." Kant wrote something similar in the Metaphysics of Morals. He suggests that parents have obligations to their children because they "brought a person into the world without his consent" and so they "incur an obligation to make the child content with his condition so far as they can" (MS 6:280). For more on the Kantian justification, see Puls (2016). Many discussions of parental obligations support this claim that parents ought to develop their child's autonomy.

${ }^{18}$ Brighouse and Swift assert this obligation unequivocally, going so far as claiming that state intervention would be justified: "For us, children have a vital interest in developing the capacity for autonomy, and parents harm children - in ways that the state may legitimately seek to prevent - when they deny them the kind of upbringing that develops that capacity" $(2014,12)$.
} 
but it can be justified by an appeal to the child's autonomy. ${ }^{19}$ A child who is deprived of an education will never be able to consider a wide variety of possibilities and freely choose what kind of life she wants to pursue. Many philosophers of education argue that fostering autonomy should be one of the principal aims of education. ${ }^{20}$ Thus, the idea that teachers ought to promote students' autonomy has seemed plausible for a variety of reasons; one need not reach this conclusion by way of Kant's ethics or Rousseau's Émile.

There is considerable overlap here between education and parenting. Much of the philosophy of parenting literature revolves around the nature of parental obligations, and promoting the child's autonomy is commonly cited as one of the most important parental obligations. ${ }^{21}$ The reasons are quite similar to those given for education: it is often argued that it would be wrong for a parent to foreclose possible life choices, careers, or opportunities for flourishing. Feinberg (1980) puts forward a very convincing argument that parents have an obligation to respect the child's "right to an open future" and cultivating the child's autonomy and capacities is an essential component of this obligation.

\footnotetext{
${ }^{19}$ See Brighouse (1998) and (2005) for a defense of a particularly autonomy-oriented curriculum within the framework of liberalism.

${ }^{20}$ Many of these discussions cite Justice Douglas's dissent in Wisconsin v Yoder as they argue for the importance of autonomy in education. This is a prominent theme in the work of Harry Brighouse and is central to the literature on education and liberalism. See Brighouse (1998, 2005). See also Schouten (2018), Levinson (1999), Barrow and Woods (2006), Gutmann (1987), Macedo (1990), Callan (1997). Although many of these discussions are about civic education and liberal legitimacy, an incredibly diverse set of perspectives converge on this conclusion. See, for example, Frierson (2016) and (2021) on Maria Montessori. See Morgan (2013) for a Buddhist justification. The idea that education ought to facilitate autonomy may strike some as too obvious to need further argument. As Paul Smeyers puts it, "In its most general terms, education and child rearing is centrally concerned with autonomy" (Smeyers 2012, 1).

${ }^{21}$ There are many arguments to this effect in the literature. Following Feinberg (1980), many of them stress the importance of presenting the child with a wide variety of possibilities so that the future is open to them. See also Brighouse and Swift (2014). But the capacity to consider different conceptions of the good is not by itself sufficient. Callan (2002) argues that parents should also develop the child's capacity to adhere to their chosen conception of the good. Callan's point is especially useful for our argument below.
} 
This might already be enough to justify the claim that teachers and parents ought to promote the autonomy of their students and children. And some readers may not require much convincing on this point, as the idea has great intuitive plausibility. Surely teachers and parents have some obligations in this regard. What may require more of an argument, however, is the claim that the duty to promote autonomy extends to the use of technology. Why should we think that parents and teachers ought to promote the end of digital minimalism?

We will not defend the existence of this obligation by pointing to the fact that many parents already believe that they have a duty to protect their children from addictive technology. But it is an interesting place to start, for we might want to know why so many parents believe these actions are justified. One seemingly ironic instance of this parenting trend was the recent flurry of headlines about Silicon Valley parents who either ban or severely limit their children's access to screens. This should not surprise us at all. Software developers and social media companies are keenly aware of how addictive their products are. As we explained in section 2, many apps and social media sites are deliberately engineered to be addictive, seeking to trigger dopamine surges to keep users coming back as much as possible.

And this is precisely why developers want to protect their children from these products. As one of them put it:

"On the scale between candy and crack cocaine, it's closer to crack cocaine ... We thought we could control it, and this is beyond our power to control. This is going straight to the pleasure centers of the developing brain. This is beyond our capacity as regular parents to understand" (Bowles 2018). 
Another waxed poetic about the risk: "I am convinced the devil lives in our phones and is wreaking havoc on our children" (ibid).

It is not only the developers who have taken notice. Organizations like the American Academy of Pediatrics and the World Health Organization have recommended that children under the age two get no screen time at all (except for video calls) and children from two to five should get less than an hour a day (Pappas 2020). In addition to the risk of developmental delays that are associated with screen usage at young ages (speech, socialization, etc.), researchers have found the time away from screens is "critical for developing essential life skills such as self-regulation" (CPS 2017).

Given what was said above, the link between screen time and diminished capacity for self-regulation should not be terribly surprising. As Eyal (2014) pointed out, surges of dopamine not only prompt us to seek the reward by repeating the behavior, they also suppress our capacity for judgment and reason. And, as we explained, the empirical evidence suggests that the problematic use of technology weakens our cognitive capacities in a variety of ways. The more we become addicted to the dopamine reward cycle that smartphones and social media are so good at providing, the worse we become at certain cognitive tasks.

It is for precisely this reason that Aylsworth and Castro (2021) argue that technological addiction poses a threat to rational agency (what Kant calls 'humanity'). The problematic use of smartphones is not merely inconsistent with higher-order desires, it can undermine our capacity to pursue some of our autonomous desires. The desire to read books (and the capacity to fulfill that desire) is perhaps the most salient example. One of the dangers posed by digital media is that even when we are reading on smartphones or tablets, we are often skimming, spotting keywords, 
clicking links, and switching tasks. The brain's response to this kind of activity, which Carr (2010) calls "shallow" reading, is quite different from its response to "deep reading," which requires sustained attention and more demanding cognitive processing. Given the plasticity of our brains, Carr argues that we weaken our capacity for deep reading as we become increasingly adapted to shallow reading. ${ }^{22}$

Wolf (2018) shows what the implications of these findings are for promoting literacy in children. Unsurprisingly, the recommendation is to limit children's screen time at young ages and to introduce screens thoughtfully and deliberately as the children mature. ${ }^{23}$ And that is exactly what we believe the duty to be an attention ecologist entails. Promoting digital minimalism as an end for others does not mean eschewing technology altogether. After all, smartphones and laptops are invaluable tools that can enhance our agency in a variety of ways. The (potentially difficult) task for parents and teachers is to promote the kind of thoughtful use of these tools that is conducive to autonomy, while guarding against the compulsive or addictive usage that undermines autonomy.

\footnotetext{
${ }^{22}$ Carr's conclusion might sound speculative (and he often demonstrates his points anecdotally), but several studies in psychology and neuroscience have corroborated his claim. Brand et al. (2014) used neuroimaging to demonstrate the effect of internet addiction on prefrontal control. Loh and Kanai (2014) showed how multi-tasking was associated with "smaller gray-matter density in the anterior cingulate cortex." Loh and Kanai's (2016) review of the literature explores both sides, citing some studies that confirm Carr's findings and some that cast doubt on it. But the conclusion for internet addictive behaviors is unequivocal. There is a strong link between problematic use and cognitive deficits, and these deficits are indeed "associated with alterations in brain networks involved in self-control and reward-processing" (Loh and Kanai 2016, 516).

${ }^{23}$ She also underscores the importance of parents being present when the child uses screens. Wolf (2018) shares many of the above mentioned concerns about literacy and the capacity for deep processing. Wolf spent decades researching the neuroscience of literacy (looking at technology and the "biliterate brain" in particular) and the book explains the many ways that this capacity is currently threatened. As we have argued here, the role of dopamine-fueled addiction cycles is key. Wolf cites Levitin on this point: "In multitasking we unknowingly enter an addiction loop as the brain's novelty centers become rewarded for processing shiny new stimuli, to the detriment of our prefrontal cortex, which wants to stay on task and gain the rewards of sustained effort and attention" (Wolf 2018, p.109). Wolf points out how this is especially disconcerting when it comes to children because their prefrontal cortexes are not yet fully developed and thus they are "completely at the mercy of one distraction after another."
} 
Striking this balance might be difficult, but the empirical data suggest that this is what parents, who are concerned about their children's autonomy, ought to do. Sziron and Hildt (2018) present empirical evidence in favor of this conclusion, and they tie it explicitly to Feinberg's notion of an open future. There is no denying that phones can be used to promote autonomy. In some cases, users can even harness addictive "Hook Cycles" in ways that help them pursue their ends. As Aylsworth (2022) argues, someone might use push notifications to remind herself of a successful streak in order to keep up her habit of exercising or studying German. Rather than undermining her agency, the addictive dopamine cycle helps the agent pursue her autonomous ends. Relying on Christman's (1991) model of autonomous desire, Aylsworth suggests that the desire to check the phone is autonomous because the user could reflectively endorse the process by which the desire was formed. In some cases, however, the outcome of the "Hook Cycle" is far less beneficial. For instance, one might start using an addictive app mindfully but overtime succumb to value capture, which occurs when our subtle and hard-to-express values are gamified via simplification and quantification and, over time, come to occupy the roles once played by our rich and subtle values (Nguyen 2021). Value capture can undermine autonomy if (but not only if) we follow Christman in understanding autonomy as involving freedom from alienated desire: value capture is one process by which agents internalize desires that they would not reflectively endorse upon reflection of the process by which those desires were formed.

Parents and teachers are in a uniquely privileged position when it comes to shaping how their children and students engage with technology. If we believe that parents and teachers have a duty to promote autonomy, and if we believe that the problematic use of technology poses a threat to autonomy, then we should conclude that parents and teachers have a duty to protect 
their children and students from this threat. For parents, the duty to be an attention ecologist involves limiting screen time in young children and introducing it thoughtfully to older children. For teachers, it may require careful consideration of classroom technology policies.

\subsection{Other Roles: Employers, Software Developers, and Policy Makers}

Our remarks in this section will be somewhat programmatic, as we can provide only a rough sketch of what the duty to be an attention ecologist would require in other domains. The reason for this limitation is that one's ability to set ends for others is restricted both morally and pragmatically by the nature of the relationship in question. We have restricted our attention here to three domains, and we will comment only briefly on why the duty extends to these cases and how it differs from that of parents and teachers. We will consider employers, software developers, and policy makers.

Employers (managers, bosses, administrators, etc.) are similar to teachers and parents to the extent that they are in a privileged position when it comes to setting ends for their employees. One important difference is that employers do not have the same kinds of obligations to promote or cultivate their employee's autonomy. They do, however, have an obligation to respect their employees' autonomy. The terms of employment must not undermine an employee's self-governance — their capacity to set and pursue ends.

Elizabeth Anderson (2017) highlights the extent to which employers' power can become tyrannical when they dominate employees in objectionable ways (and there are few things that Kant found as objectionable as this kind of domination). ${ }^{24}$ Anderson highlights cases where

\footnotetext{
${ }^{24}$ See Remarks 20:91-92.
} 
employers control employees' diet, clothing, political speech, and use of drugs. $(2017,39)$. We would like to extend her analysis of domination to the ways that employers require workers to engage with technology. This is particularly troubling in cases where employers require employees to be in constant communication by email or through other digital channels (e.g., Slack, text message, WhatsApp, etc.). Under these conditions, an employee is never truly off the clock, and this all but necessitates an unhealthy relationship with one's smartphone (or computer or tablet).

Cal Newport (2021b) argues that these working conditions predictably lead to burnout and high turnover. He suggests that these policies are not in employers' best interests as they paradoxically undermine productivity rather than promote it. But he is particularly concerned about the effect this has on employees' well-being. When employers require "slavish devotion to in-boxes and chat channels, then this adds up to a whole lot of global miserableness! From a utilitarian perspective, this level of suffering cannot be ignored-especially if there is something that we might be able to do to alleviate it" (2021a). Newport may very well be right about these harms, and a utilitarian argument can be leveled against this practice. But according to the moral framework we have suggested in this paper, there is another morally problematic feature of these work environments — they undermine employees' autonomy.

As we explained above, employers are not under the same kinds of obligations as parents and teachers. The cultivation of autonomy is arguably a constitutive aim of parenting and teaching, but the same cannot be said about employment. There is, nevertheless, a moral duty here, and it may be even stricter. Duties to promote the ends of others are imperfect or wide; how and to what extent parents and teachers promote autonomy is a matter of discretion. On Kant's 
view, when you have an imperfect duty to set and pursue an end, your compliance with the duty is meritorious and deserves praise, but you are not blameworthy for failing to promote the end in every possible instance. ${ }^{25}$ By contrast, when an employer treats an employee as a mere means, this is a violation of a perfect duty of respect, and all such failures are forbidden and blameworthy. ${ }^{26}$

Software developers (and those who market their products) are under a similar obligation to respect users' humanity and to refrain from treating them as a mere means. To understand the problematic cases, it may help to highlight the contrast with permissible ones. In many cases, our use of smartphones or tablets is perfectly consistent with our autonomy. As noted above, we might download apps to learn German, or to remind ourselves to exercise, or even (ironically) to spend less time looking at our phones. In cases like these, if the app helps the user fulfill her ends and it does not undermine her capacities of rational agency, then there is nothing objectionable about this mutually beneficial arrangement. Both the developer and the user are promoting their ends. No one has been used as a mere means.

\footnotetext{
${ }^{25}$ This might make it sound like all compliance with an imperfect duty is always supererogatory, but that is not the case. Failure to set an obligatory end at all is a violation of the imperfect duty and is blameworthy.

${ }^{26}$ In order to ward off a possible misinterpretation, we should clarify that Kant does not object to wage labor in general and he does not see it as a case of treating a person as a "mere means." Allen Wood explains how wage labor contracts are valid under Kant's account in the Doctrine of Right ( $M S$ 6:285) while nevertheless showing how a Marxist objection could be raised about the potentially exploitative conditions under which a worker agrees to a labor contract (Wood 2017). Our worry about these working conditions is importantly distinct from the Marxist objection to wage labor. The Marxist objection suggests that all forms of wage labor under capitalism are exploitative; our claim is one sense weaker, since it does not condemn all wage labor and in another sense stronger since it identifies as problematic working conditions that could hold under other forms of labor (e.g., if one's co-op uses a distractive, anxiety-inducing messaging platform).

Like Anderson, we think that some forms of employment involve problematic domination, and our concern here is that certain working conditions (such as those that require constant contact through digital media) might undermine employee's capacities in a way that is inconsistent with the obligation to respect humanity. "The duty of respect for my neighbor is contained in the maxim not to degrade any other to a mere means to my ends (not to demand that another throw himself away in order to slave for my end)" (MS 6:450). When the terms of employment diminish the employee's capacities (and thus disrespect her humanity), this is tantamount to demanding that she throw herself away for the employers' ends.
} 
Not all cases of software development are so benevolent, however. The model proposed by Eyal (2014) is a clear example of what morally problematic software development could look like. If a developer deliberately harnesses the psychology of addiction in order to maximize the time that users spend looking at an app, it is easy to see how this fails to respect the rational agency of the user. By instilling a compulsive desire to return to an app, the developer treats the user more like Pavlov's dog than a rational agent. ${ }^{27}$

But developers might raise the following objection in response to this concern. People are clearly enjoying these apps. Perhaps the products are addictive simply because users are getting so much enjoyment out of them. How is that morally problematic?

There are several ways of replying to this objection. ${ }^{28}$ But the reply suggested by the account we have defended here is that there are moral concerns about certain uses of technology even when users seem to be enjoying the products. If our use of these devices undermines our capacities for self-governance and makes us less capable of setting and pursuing ends, then this usage is problematic regardless of our enjoyment.

In order to avoid treating users as mere means, developers ought to take users' rational agency into consideration. Products should be developed with an eye toward the effects they have on users and their capacities for self-governance. They should also avoid the manipulative tactics that have contributed to problematic usage. Indeed, many of these suggestions have been made by developers and executives who became disillusioned with the industry and left it to

\footnotetext{
${ }^{27}$ Noggle (1995) defends an account of "alien desires" that explains why someone might think that creating desires in this way is "deeply repugnant." On his view, when an alien desire is the product of this kind operant conditioning, the desires are predicated on "discordant quasi-beliefs" that were not formed by the agent's rational capacities, are not available upon introspection and that the agent would not endorse.

${ }^{28}$ The use of manipulative tactics might be objectionable even when users are enjoying the apps. Noggle (1995) makes such an argument. Furthermore, the empirical findings in section 2 show how users often return to the apps and social media sites even when doing so is not conducive to their well-being.
} 
become vocal critics of these products and the effects they have on users. They frequently recommend that tech companies should stop exploiting these psychological vulnerabilities so that users can autonomously decide how and to what extent to use their devices.

Perhaps the most notable example of this is Tristan Harris, a former design ethicist at Google. He was issuing warnings about this problem as far back as 2013 when he gave a presentation to fellow Googlers titled, "A Call to Minimize Distraction \& Respect Users' Attention." After leaving Google in 2016, he founded a non-profit organization called the "Center for Humane Technology," and he suggests that tech companies should do more to promote healthier relationships with technology. He is particularly concerned with the way that these companies have leveraged the psychology of anxiety and addiction to hook users on the products. But he points out why they might be reluctant to change, saying that the problem is that “Successful products compete by exploiting these vulnerabilities, so they can't remove them without sacrificing their success and growth" (Harris 2013). Sean Parker, ex-president of Facebook, claims that Facebook "founders knew they were creating something addictive that exploited 'a vulnerability in human psychology' from the outset” (Solon 2017). He identified two of the concerns that we have raised in this paper: "It literally changes your relationship with society, with each other. It probably interferes with productivity in weird ways. God only knows what it's doing to our children's brains" (ibid).

This brings us the final role that we will consider in this section. What, if anything, should policy makers do about this issue? Some of the arguments that have been made in favor of regulating the attention economy make use of consequentialist considerations. ${ }^{29}$ But the

\footnotetext{
${ }^{29}$ See, for instance, See Castro and Pham (2020).
} 
Kantian framework is far less amenable to arguments of that kind. Kant's ethics would not be able to justify restricting the freedom of developers or tech companies as a means of promoting the happiness of other citizens. Indeed, Kant claimed that using state coercion to promote happiness (as the state conceives it) violates its subjects' freedom and thus constitutes the “greatest despotism thinkable" (TP 8:290-91).

But there is still room for a Kantian argument in favor of regulation. Our remarks here must be brief, because the argument for regulation stems from a different set of commitments than those we presented above. Kant's moral philosophy draws a sharp distinction between duties of right and duties of virtue. Duties of right are those that can be justifiably enforced by coercion through the state; whereas duties of virtue are moral duties that the state should not enforce (MS 6:219-20). The duty to be an attention ecologist, as we have defended it so far, is a duty of virtue. Issues of regulation and liberty concern duties of right.

It would be impossible to do justice to Kant's political philosophy here, so the following will be only a rough sketch. In short, what emerges from Kant's social contract theory in the Metaphysics of Morals is a form of classical liberalism. ${ }^{30}$ At a minimum, it shares liberalism's foundational commitment to freedom. Kant makes freedom the bedrock of his Doctrine of Right, and he believes that the state should use its coercive power only in ways that promote freedom. Kant is aware of the apparent paradox. Limiting freedom to promote freedom may sound like an outright contradiction when stated naively.

He defines coercion as "any limitation of freedom through another's choice," while nevertheless advocating a civil condition in which free human beings are "subject to coercive

\footnotetext{
${ }^{30}$ Contemporary liberals (following Rawls) distinguish between "political" and "comprehensive liberalism" where the latter is bound up with a particular conception of "what is of value in human life" (175), and Rawls points out how Kant's liberalism is comprehensive given his view on the "ethical value of autonomy" (Rawls 2005, 99).
} 
laws" (TP 8:290). He resolves this apparent tension by arguing that justifiable acts of coercion are not merely a hindrance to freedom. Legitimate coercion consists in the "hindering of a hindrance of freedom" (MS 6:231). As Ripstein (2009) puts it, "Coercion is objectionable where it is a hindrance to a person's right to freedom, but legitimate when it takes the form of hindering a hindrance to freedom. To stop you from interfering with another person upholds the other's freedom" (55).

When it comes to considering legislation that would hinder the freedom of software developers, Kant's political philosophy leaves room for the legitimacy of such a law on the grounds that we are hindering a hindrance to the freedom of others. By allowing software developers to enjoy unfettered freedom to get people addicted to smartphones or social media, we are inhibiting the freedom of users.

Although we cannot offer many specific policy recommendations here, we hope that this account lays the groundwork for a Kantian justification of such regulations. One area where such regulation might seem especially pressing is the marketing of apps, tablets, and smartphones to children. As Castro and Pham (2020) note, the obvious precedent to cite here would be cigarettes. After decades of litigation, tobacco companies settled with attorneys general from nearly every state and agreed not to market cigarettes to children. They also acknowledged publicly that their products were both addictive and harmful. The problem with this comparison is that the settlement was the result of a lawsuit, not legislation. Banning advertising through legislation would have inevitably faced challenges on the grounds of free speech. But the comparison is useful nevertheless. The tobacco industry was forced to begrudgingly acknowledge that their products were addictive and harmful, and they had to make changes. The 
alarm bells coming from Silicon Valley should sound eerily familiar, and their day of reckoning may be near.

\section{Conclusion}

We have argued that smartphone addiction poses a threat to autonomy and that we have a moral obligation to protect other people from falling prey to this danger. We showed how this duty arises in contexts where we have special obligations to promote the freedom of others in virtue of our relationship with them. In some cases, like those of parents and teachers, there is a positive duty to promote autonomy given the nature of these activities and their aims. For others, such as software developers and employers, the duty to respect humanity has a negative form in that it forbids treating people as mere means by undermining their capacities for rational agency. Finally, there are policy implications of these conclusions. Insofar as we share Kant's view about the role the state plays in safeguarding freedom, there might be some justifiable regulations that lawmakers should enact in order to protect autonomy from the threat posed by the problematic use of technology. 


\begin{abstract}
Abbreviations
All citations of Kant's writings provide the volume and page numbers from the Akademie edition of Kants gesammelten Schriften. All translations are taken from the Cambridge editions.

G Groundwork for the Metaphysics of Morals in Practical Philosophy

MS Metaphysics of Morals in Practical Philosophy

Remarks Remarks in the Observations on the Feeling of the Beautiful and Sublime in Notes and Fragments

TP On the common saying: That may be correct in theory, but it does not work in practice in Practical Philosophy

UP Lectures on Pedagogy in Anthropology, History, and Education
\end{abstract}

\title{
References
}

Anderson, Elizabeth. Private Government: How Employers Rule Our Lives (and Why We Don't Talk about It). Princeton University Press.

Austin, Michael W. 2007. Conceptions of Parenthood: Ethics and The Family. 1st edition. Aldershot, England; Burlington, VT: Routledge.

Aylsworth, Timothy (2022). Autonomy and Manipulation: Refining the Argument Against Persuasive Advertising. Journal of Business Ethics 175 (4):689-699. https://www.doi.org/10.1007/s10551-020-04590-6

Aylsworth, Timothy, and Clinton Castro. 2021. "Is There a Duty to Be a Digital Minimalist?” Journal of Applied Philosophy, February, japp.12498. https://doi.org/10.1111/japp.12498.

Bacin, Stefano. 2021. "My Duties and the Morality of Others: Lying, Truth and the Good Example in Fichte's Normative Perfectionism." In Fichte's System of Ethics: A Critical Guide.

Barrow, R. and Woods, R. 2006. An Introduction to the Philosophy Of Education, 4th edn. (London, Routledge)

Beningfield, Jamie. 2021. "Study Reveals How Often We Look At Our Phones In A Day" BrainSharper https://www.brain-sharper.com/entertainment/how-often-look-phones-day/ Blustein, Jeffrey. 1982. Parents and Children: The Ethics of the Family. New York: Oxford University Press. 
Bowles, Nellie. 2018. “A Dark Consensus about Screens and Kids Begins to Emerge in Silicon Valley." The New York Times. https://www.nytimes.com/2018/10/26/style/phones-children-silicon-valley.html

Brand, Matthias, Kimberly S. Young, and Christian Laier. 2014. "Prefrontal Control and Internet Addiction: A Theoretical Model and Review of Neuropsychological and Neuroimaging Findings." Frontiers in Human Neuroscience 8: 375. https://doi.org/10.3389/fnhum.2014.00375.

Bratman, Michael. 1979. "Practical Reasoning and Weakness of the Will," Nous, 13, 2.

—. Structures of Agency: Essays (Oxford: Oxford University Press, 2007).

Brewer, J. 2021. Unwinding Anxiety: New Science Shows How to Break the Cycles of Worry and Fear to Heal Your Mind. United States: Penguin Publishing Group.

Brighouse, Harry. 1998. “Civic Education and Liberal Legitimacy.” Ethics 108 (4): 719-45. https://doi.org/10.1086/233849.

- 2005. On Education. London; New York: Routledge.

Brighouse, Harry, and Adam Swift. 2014. Family Values: The Ethics of Parent-Child Relationships. Princeton University Press.

Brumby, D., Cox, A., and Back, J. (2013). Recovering from an interruption: investigating speed-accuracy tradeoffs in task resumption strategy. J. Exp. Psychol. Appl. 19, 95-107. doi: $10.1037 / \mathrm{a} 0032696$

Cades, D. M., Davis, D. A. B., Trafton, J. G., and Monk, C. A. (2007). "Does the difficulty of an interruption affect our ability to resume?," in Proceedings of the Human Factors and Ergonomics Society 51st Annual Meeting, Santa Monica, CA, 234-238. doi: $10.1177 / 154193120705100419$

Cain, N., and Gradisar, M. (2010). Electronic media use and sleep in school-aged children and adolescents: a review. Sleep Med. 11, 735-742. doi: 10.1016/j.sleep. 2010.02 .006

Callan, Eamonn. 1997. Creating Citizens: Political Education and Liberal Democracy. Oxford, Clarendon Press.

- 2002. "Autonomy, Child-Rearing, and Good Lives." In The Moral and Political Status of Children, edited by David Archard and Colin M. Macleod, 118-41. Oxford University Press.

Canadian Paediatric Society (CPS), Digital Health Task Force, Michelle Ponti, Stacey Bélanger, Ruth Grimes, Janice Heard, Matthew Johnson, Elizabeth Moreau, et al. 2017. "Screen 
Time and Young Children: Promoting Health and Development in a Digital World." Paediatrics \& Child Health 22 (8): 461-68. https://doi.org/10.1093/pch/pxx123.

Carr, Nicholas G. 2010. The Shallows: What the Internet Is Doing to Our Brains. W. W. Norton \& Company.

Castro, Clinton \& Pham, Adam (2020). Is the Attention Economy Noxious? Philosophers' Imprint 20 (17):1-13.

Christman, John. “Autonomy and Personal History." Canadian Journal of Philosophy 21, no. 1 (January 1991): 1-24.

Cohen, Alix. "The Role of Feelings in Kant's Theory of Moral Education." Journal of the Philosophy of Education 50:511-23.

Denis, Lara.. 1999 "Kant on the Perfection of Others." The Southern Journal of Philosophy 37 (1): 21-41. https://doi.org/10.1111/j.2041-6962.1999.tb00855.x.

- 2001. Moral Self-Regard: Duties to Oneself in Kant's Moral Theory. New York, NY: Routledge.

Dworkin, Gerald. 1988. The Theory and Practice of Autonomy (Cambridge; New York: Cambridge University Press).

Ell, Kellie. 2018. "Ex-Google Employee Calls Tech Addiction an 'Existential Threat' and Calls for Regulation" CNBC. https://www.cnbc.com/2018/02/07/ex-google-employee-calls-tech-addiction-an-existentia 1-threat.html

Eyal, Nir. Hooked: How to Build Habit-Forming Products (New York: Penguin Books Limited, 2014)

Feinberg, Joel. "The Child's Right to an Open Future" in William Aiken and Hugh LaFollette (eds), Whose Child?: Children's Rights, Parental Authority, and State Power (Totowa, NJ: Littlefield, Adams, and Co., 1980): 124-153. Reprinted in Curren, Randall, ed. 2006. Philosophy of Education: An Anthology. 1st edition. Malden, MA: Wiley-Blackwell.

Fichte, Johann Gottlieb. 2005. Fichte: The System of Ethics. Edited by Daniel Breazeale and Guenter Zöller. 0 edition. Cambridge, UK ; New York: Cambridge University Press.

Frankfurt, Harry. 1971. 'Freedom of the will and the concept of a person', Journal of Philosophy, 68, 1 (1971): 5-20

Frierson, Patrick R. 2016. “Making Room for Children's Autonomy: Maria Montessori's Case for Seeing Children's Incapacity for Autonomy as an External Failing: Making Room for 
Children's Autonomy." Journal of Philosophy of Education 50 (3): 332-50.

https://doi.org/10.1111/1467-9752.12134.

— 2021. "The Moral Philosophy of Maria Montessori." Journal of the American

Philosophical Association 7 (2): 133-54. https://doi.org/10.1017/apa.2019.41.

—. (forthcoming). "Kant on Education." in Gomes, A. and Stephenson, A. (eds.) The

Oxford Handbook of Kant (Oxford: Oxford University Press)

Gutmann, Amy. 1987. Democratic Education. Princeton, NJ, Princeton University Press.

Harris, Tristan. 2013. "A Call to Minimize Distraction \& Respect Users’ Attention.”

http://www.minimizedistraction.com/

Herman, Barbara. 2007. Moral Literacy. Harvard University Press.

Kant, Immanuel. Groundwork of the Metaphysics of Morals. In Practical Philosophy. Trans. M.

J. Gregor. Cambridge, U.K.

- 2008. Metaphysics of Morals in Practical Philosophy. Trans. M. J. Gregor. Cambridge.

—. 2005. Notes and Fragments. Trans. C. Bowman/P. Guyer/F. Rauscher. Cambridge.

Korsgaard, Christine M. 1992. "Creating the Kingdom of Ends: Reciprocity and Responsibility in Personal Relations." Philosophical Perspectives

-1996. The Sources of Normativity. Cambridge; New York: Cambridge University Press.

Levitin, Daniel J. 2014. The Organized Mind: Thinking Straight in the Age of Information Overload. Penguin.

Lim, J., and Dinges, D. F. (2008). Sleep deprivation and vigilant attention. Ann. N. Y. Acad. Sci. 1129, 305-322. doi: 10.1196/annals.1417.002

Leiva, L., Bohmer, M., Gehring, S., and Krüger, A. Back to the app: the costs of mobile application interruptions. In Proc. Mobile HCI (2012).

Levinson, Meira. 1999. The Demands of Liberal Education. Oxford, Oxford University Press.

Loh, Kep Kee, and Ryota Kanai. 2014. "Higher Media Multi-Tasking Activity Is Associated with Smaller Gray-Matter Density in the Anterior Cingulate Cortex." PLOS ONE 9 (9): e106698. https://doi.org/10.1371/journal.pone.0106698.

_ 2016. "How Has the Internet Reshaped Human Cognition?" The Neuroscientist 22 (5): 506-20. https://doi.org/10.1177/1073858415595005.

Louden, Robert. 2000. Kant's Impure Ethics: From Rational Beings to Human Beings. Oxford University Press.

Macedo, Stephen. 1990. Liberal Virtues. Oxford, Oxford University Press. 
Mann, S. (2016). The Science of Boredom: Why Boredom is Good. United Kingdom: Little, Brown Book Group.

McIntyre RS, Xiao HX, Syeda K, et al. The prevalence, measurement, and treatment of the cognitive dimension/domain in major depressive disorder. CNS Drugs. 2015;29(7):577-589. doi:10.1007/s40263-015-0263-X

Millan MJ, Agid Y, Brüne M, et al. Cognitive dysfunction in psychiatric disorders: characteristics, causes and the quest for improved therapy. Nat Rev Drug Discov. 2012;11(2):141-168. doi:10.1038/nrd3628

Monk, C. A. (2004). "The effect of frequent versus infrequent interruptions on primary task resumption," in Proceedings of the Human Factors and Ergonomics Society 48th Annual Meeting, Santa Monica, CA, 295-299. doi: 10.1177/154193120404800304

Monk, C. A., Trafton, J. G., and Boehm-Davis, D. A. (2008). The effect of interruption duration and demand on resuming suspended goals. J. Exp. Psychol. Appl. 14, 299-313. doi: $10.1037 / \mathrm{a} 0014402$

Morgan, Jeffrey. 2013. "Buddhism and Autonomy-Facilitating Education." Journal of Philosophy of Education 47 (4): 509-23. https://doi.org/10.1111/1467-9752.12031.

Newport, Cal. 2021a. "E-mail is Making Us Miserable.” The New Yorker. https://www.newyorker.com/tech/annals-of-technology/e-mail-is-making-us-miserable

- 2021b. A World Without Email: Reimagining Work in an Age of Communication Overload. Portfolio.

Nguyen, C. Thi (2021). How Twitter gamifies communication. In Jennifer Lackey (ed.), Applied Epistemology. Oxford University Press. pp. 410-436.

Noggle, Robert. 1995. “Autonomy, Value, and Conditioned Desire.” American Philosophical Quarterly 32 (1): 57-69.

Odell, J. (2019). How to Do Nothing: Resisting the Attention Economy. United Kingdom: Melville House.

O’Neill, Onora, William Ruddick, and Society for Philosophy and Public Affairs, eds. 1979. Having Children: Philosophical and Legal Reflections on Parenthood: Essays. New York: Oxford University Press.

-1980. "The Moral Perplexities of Famine and World Hunger." In Matters of Life and Death, ed. Tom Regan, 260-98. New York: Random House.

. 1986. Faces of Hunger. London: Allen \& Unwin. 
Pappas, Stephanie. 2018. "What Do We Really Know about Kids and Screens?” American Psychological Association. Accessed August 29, 2021. https://www.apa.org/monitor/2020/04/cover-kids-screens.

Provision Living. Smartphone Screen Time: Baby Boomers and Millennials. (2020, June 25). https://www.provisionliving.com/news/smartphone-screen-time-baby-boomers-and-mille nnials.

Puls, Heiko. 2016. "Kant's Justification of Parental Duties.” Kantian Review 21 (1): 53-75. https://doi.org/10.1017/S1369415415000308.

Rawls, John. 2005. Political Liberalism. Columbia University Press.

Re, Stefano Lo. 2022. "The Glowing Screen Before Me and the Moral Law Within Me: A Kantian Duty Against Screen Overexposure.” Res Publica, 1-21. https://doi.org/10.1007/s11158-021-09538-9.

Ripstein, Arthur. 2009. Force and Freedom: Kant's Legal and Political Philosophy. Harvard University Press.

Roth, Klas, and Paul Formosa. 2019. "Kant on Education and Evil-Perfecting Human Beings with an Innate Propensity to Radical Evil." Educational Philosophy and Theory 51 (13): 1304-7. https://doi.org/10.1080/00131857.2019.1520357.

Schouten, Gina. 2018. "Political Liberalism and Autonomy Education: Are Citizenship-Based Arguments Enough?” Philosophical Studies 175 (5): 1071-93. https://doi.org/10.1007/s11098-018-1071-1.

Smeyers, Paul. 2012. "Chains of Dependency: On the Disenchantment and the Illusion of Being Free at Last (Part 1).” Journal of Philosophy of Education 46 (2): 177-91. https://doi.org/10.1111/j.1467-9752.2012.00845.x.

Sohn, Sei Yon, Rees, Philippa, Wildridge, Bethany, Kalk, Nicola J., and Carter, Ben. Prevalence of problematic smartphone usage and associated mental health outcomes amongst children and young people: a systematic review, meta-analysis and GRADE of the evidence. BMC Psychiatry 19, 356 (2019). https://doi.org/10.1186/s12888-019-2350-x

Solon, Olivia. 2017. "Ex-Facebook president Sean Parker: site made to exploit human "vulnerability", The Guardian. https://www.theguardian.com/technology/2017/nov/09/facebook-sean-parker-vulnerabilit y-brain-psychology

Stothart, C., Mitchum, A., and Yehnert, C. (2015). The attentional cost of receiving a cell phone notification. J. Exp. Psychol. 41, 893-897. doi: 10.1037/xhp0000100 
Sziron, Monika, and Elisabeth Hildt. 2018. "Digital Media, the Right to an Open Future, and Children 0-5." Frontiers in Psychology 0. https://doi.org/10.3389/fpsyg.2018.02137.

Taylor, Robert S. 2005. “Kantian Personal Autonomy.” Political Theory 33 (5): 602-28. https://doi.org/10.1177/0090591705278397.

Thornton, B., Faires, A., Robbins, M., and Rollins, E. (2014). The mere presence of a cell phone may be distracting implications for attention and task performance. Soc. Psychol. 45, 479-488. doi: 10.1027/1864-9335/a000216

Vallentyne, Peter. 2002. "Equality and the Duties of Procreators." In The Moral and Political Status of Children. Oxford: Oxford University Press.

Villarán, Alonso. 2017. "Irrational Advertising and Moral Autonomy." Journal of Business Ethics 144 (3): 479-90. https://doi.org/10.1007/s10551-015-2813-z.

Waldron, Jeremy. 2005 "Moral Autonomy and Personal Autonomy," in Autonomy and the Challenges to Liberalism, eds. John Christman and Joel Anderson (Cambridge: Cambridge University Press), 308-14.

Watson, Gary. 1975, "Free agency," The Journal of Philosophy, 72, 8: 205-20, p 220.

Wilmer, H. H., Sherman, L. E., \& Chein, J. M. (2017). Smartphones and Cognition: A Review of Research Exploring the Links between Mobile Technology Habits and Cognitive Functioning. Frontiers in psychology, 8, 605. https://doi.org/10.3389/fpsyg.2017.00605

Winnick, M., \& Zolna, R. (2016, June 16). Putting a finger on our phone obsession; Mobile touches: A study on humans and their tech. Dscout. Retrieved from https://blog.dscout.com/mobile-touches

Wisconsin v. Yoder, 406 US 205

Wolf, Maryanne. 2018. Reader, Come Home: The Reading Brain in a Digital World. HarperCollins.

Wood, Allen. 1970. Kant's Moral Religion. Ithaca: Wiley-Blackwell.

- 1999. Kant's Ethical Thought. Cambridge; New York: Cambridge University Press. -. 2004. Kant. Wiley-Blackwell.

- 2016. Fichte's Ethical Thought. Oxford University Press.

- 2017. "Marx and Kant on Capitalist Exploitation." Kantian Review 22 (4): 641-59. https://doi.org/10.1017/S1369415417000310. 


\section{Funding}

The authors declare that no funds, grants, or other support were received during the preparation of this manuscript.

\section{Competing Interests}

The authors have no relevant financial or non-financial interests to disclose.

\section{Ethics approval}

$\mathrm{n} / \mathrm{a}$

Consent to participate

$\mathrm{n} / \mathrm{a}$

\section{Consent to publish}

$\mathrm{n} / \mathrm{a}$ 